\title{
Adaptability Study of Brachiaria Grass Accessions for Forage Yield and Nutritive Value in Lowlands of East Oromia, Ethiopia
}

\author{
Tolera Fikadu, ${ }^{1, *}$, Worku Bekuma ${ }^{2}$, Wubishet Tesfaye², Melese Furgasa ${ }^{1}$ \\ ${ }^{1}$ Range Ecology and Biodiversity, Fedis Agricultural Research Center, Oromia Agricultural Research Institute, Harar, Ethiopia \\ ${ }^{2}$ Animal Nutrition, Fedis Agricultural Research Center, Oromia Agricultural Research Institute, Harar, Ethiopia
}

Email address:

tolerafekadu7@gmail.com (T. Fikadu)

*Corresponding author

\section{To cite this article:}

Tolera Fikadu, Worku Bekuma, Wubishet Tesfaye, Melese Furgasa. Adaptability Study of Brachiaria Grass Accessions for Forage Yield and Nutritive Value in Lowlands of East Oromia, Ethiopia. Ecology and Evolutionary Biology. Vol. 6, No. 2, 2021, pp. 42-46.

doi: $10.11648 /$ j.eeb. 20210602.13

Received: March 23, 2021; Accepted: May 21, 2021; Published: June 25, 2021

\begin{abstract}
Livestock production in the lowlands of Eastern Oromia of Ethiopia depends mainly on natural pastures and crop residues which are of poor quality and the yield is generally low during the dry season. Therefore, there is a need to introduce alternative forages of high quality that are adapted to the region. The objective of this study was to identify and select the best Brachiaria grass accession/s for dry matter (DM) yield and nutritive quality in lowlands of Eastern Oromia. The experiment was conducted in the lowlands of Fedis and Dire-Dawa districts during 2018 to 2020 . The experimental materials were brachiaria decumbens accessions 1087, 13205, 14721, 14720 and brachiaria ruziziensis accessions 13332, 14743, 14771, 14774,14813 . These grass accessions were compared with one local check, a locally cultivated brachiaria grass. Plant established successfully at both sites for the last three years. Tiller numbers, plant height, forage dry matter yield and plot covers were recorded at 16 weeks after planting. Significant $(\mathrm{p}<0.05)$ difference were detected among the tested grass accessions in plot cover, height, tiller number, dry matter yield, OM\%, Ash\%, CP\%, NDF\%, ADF\% and ADL\% contents. The results showed that brachiaria grasses had the potential to provide forage of high quality and adequate quantity for livestock feed. Accession of brachiaria ruziziensis 14813 (24.685 t/ha) and brachiaria decumbens 14721 (20.89t/ha) showed the highest forage dry matter production than the remaining evaluated grass accessions. Although brachiaria grass accession 14720 and 13205 had higher CP content than accessions 14721, high forage dry matter yield is more appealing to farmers it is not recommended for cultivation in the study area. Thus, these two grass accessions brachiaria ruziziensis 14813 and brachiaria decumbens 14721 are the most suitable for providing better quality and quantity of livestock feed in the lowlands of Eastern Oromia, Ethiopia and similar agro-ecologies to the study area.
\end{abstract}

Keywords: Dry Matter Yield, Plant Height, Plot Cover, Tiller Numbers

\section{Introduction}

Forages play an important role in agricultural economy of developing countries by providing the cheapest source of feed for the livestock. In Eastern lowlands of Oromia, one of the most important challenges to livestock production is scarcity of feeds during the dry season. Smallholder farmers face the challenge that grazing land is gradually becoming scarcer, and their current cattle productivity is too low for effective commercialization. Farmers depend on natural pasture and crop residue for livestock and more often give low priority to pasture establishment. These available feed resources in the smallholder mixed farms are inadequate in quantity and low in quality.

Past attempts to improve livestock production in this area focused mainly on crop residues and farmers usually harvest fodder from thinned crop plants, weeds, and defoliated leaves. Despite these efforts, cultivated forages account very low contribution mainly due to lack of suitable grasses adapted to environmental conditions of the area. In addition, land sub- 
division has also contributed to feed shortage through limited available land for pasture establishment. Planting nutritious forages on small parcels of land and cut-and-carry these to feed their penned cattle can considerably increase animal production and associated income here. Particularly as beef demand of the area is increasing in the country, this presents cattle-keeping smallholders in east Oromia is with an opportunity to enhance their livelihoods. To address the challenges of feed shortage in the region, there is need to select high quality forages that are adapted to the region.

The genus Brachiaria consists of about 100 species distributed across tropical and sub-tropical region [18]. Brachiaria have advantage over those in other genera including adaptation to drought and low fertility soils, sequesters carbon through its large roots system, enhance nitrogen use efficiency and subsequently minimize eutrophication and greenhouse gas emissions $[1,12,16]$. Brachiaria plays important roles in soil erosion control and ecological restoration. Brachiaria species have been important component of sown pastures in humid low lands and savannas of tropical America with current estimated acreage of 99 million hectare in Brazil alone [9]. Africa is the center of origin of Brachiaria grasses. Brachiaria species are native to eastern and central Africa and are extensively grown as livestock forage in South America and East Asia [2]. Important species include B. ruziziensis, B. decumbens, B. brizantha and B. humidicola.

Recently, the mounting demand for livestock products in Africa has renewed interest of farmers, researchers, and development and government agencies on forages particularly to climate resilient forages like Brachiaria grass. Therefore, there have been multiple repatriations of Brachiaria grass to Africa as hybrids and improved landraces [10, 5]. These materials have shown positive performance in terms of improved forage availability and livestock productivity. These results have revealed Brachiaria as an ideal forage option for the livestock farmers in East Africa. Despite the immense benefits demonstrated of these grasses in other countries, the potential of improved Brachiaria grass in East Oromia to address the challenge of livestock feed scarcity remain unexploited and there is no information on the production and uses of these grasses in the East region. Therefore, there is a need for identifying Brachiaria grass accessions that are more productive and adaptable to the lowland production systems of Eastern Oromia, since accessions within a species differ in yield potential and quality of forage produced.

\section{Materials and Methods}

\subsection{Description of the Study Area}

The study was conducted under rain-fed conditions during 2018 and 2019 growing season in Fedis Agricultural Research Center, in Fedis District on Boko station, which is $550 \mathrm{~km}$ to the East of Addis Ababa and $24 \mathrm{~km}$ southeast of Harari city. The Fedis district is situated at an altitude of 1200 to $1600 \mathrm{~m}$ and $1500 \mathrm{~m}$ of boko station above sea level,
[4]. The amount of rainfall varies between 650 and $750 \mathrm{~mm}$, while the average temperature of the district ranges between 25 and $30{ }^{\circ} \mathrm{C}$ [22]. In the vicinity of the site; Vertisols and Afilsols soil type are common to the area. Soil is loam [3].

\subsection{Experimental Design and Treatments}

The experiment was conducted from 2018 to 2020 at two locations for the last three years. The grass accessions were brachiaria decumbens accessions 1087, 13205, 14721, 14720 and brachiaria ruziziensis accessions 13332, 14743, 14771, 14774, 14813 and one local check. All the experimental materials were obtained from Holeta Agricultural Research Center of Ethiopia Except the local check. The treatments were laid out in a randomized complete block design with three replications. The plot sizes were $4 \mathrm{~m} \times 3 \mathrm{~m}$ with a $1 \mathrm{~m}$ path between plots and $1.5 \mathrm{~m}$ between blocks respectively. The grass roots were planted at about $0.5 \mathrm{~m}$ and $0.25 \mathrm{~m}$ between rows and plants respectively on a well prepared seed bed.

\subsection{Data Collection}

Plant height, plot cover and tiller number at 16 weeks after planting in both sites. At the end of 16 weeks after planting, the plants were harvested for dry matter (DM) yield determination. Plant height was determined by measuring the primary shoots from the base of the plant to the topmost flag leaf of four tagged plants as described by Rayburn and Lozier [17]. The percentage plot cover was determined from a $1 \mathrm{~m} \mathrm{x}$ $1 \mathrm{~m}$ quadrat sub-divided into 25 squares as described by Njarui and Wandera [14]. Tillers were counted for tagged plants. During the DM yield determination, the plants were cut to a stubble height of $5 \mathrm{~cm}$ in an area of $4 \mathrm{~m}^{2}$. Fresh herbage was harvested, weighed and a sub-sample taken, oven dried at of $65^{\circ} \mathrm{C}$ to a constant weight and dry weights recorded. The nutrient analysis of Organic matter (DM\%), Ash\%, Crude protein (CP\%), Neutral Detergent Fiber (NDF\%), Acid Detergent Fiber (ADF\%) and Acid Detergent Lignin (ADL\%) were conducted at Haramaya University.

\subsection{Data Analysis}

The values on growth parameters and dry matter yields were statistically evaluated by analysis of variance (ANOVA) using general linear model (GLM) procedure of Statistical Analysis Software to perform ANOVA (SAS 9.1). Means were separated using the least significant difference (LSD) test at $\mathrm{p}<0.05[6]$.

\section{Result and Discussions}

\subsection{Brachiaria Grass Accessions Plant Height, Plot Cover, Tiller Number and Dry Matter Yield}

The composite means of the growth parameters (height, plot cover, tiller numbers and dry matter yield) during the establishment period are presented in Table 1. There were significant $(p<0.05)$ differences in plot cover, plant height, tiller numbers and dry matter yield among the grass 
accessions. The plot cover and plant height of the tested brachiaria accessions ranges from around $20 \%$ to $100 \%$ and $66.05 \mathrm{~cm}$ to $155 \mathrm{~cm}$ respectively. The grass accessions 14813 $(100 \%$ and $143 \mathrm{~cm})$ and 14721 (100\%and $155 \mathrm{~cm})$ consistently recorded the highest plot cover and plant height in all the observations although it was not higher $(\mathrm{P}>0.05)$ than most of the grass accessions (Table 1). Accession 1087 had significantly the lowest plot cover $(20 \%)$ and maintained the lowest plant height $(66.05 \mathrm{~cm})$ although it was not lower $(\mathrm{P}>0.05)$ than 13205 grass accessions in plant height (Table 1). The difference in plot cover among the grass accessions might be attributed to differences in growth rate among the grasses accessions. The delay or slow to establish from the planted root may took time build reasonable plot cover and height. The plant tiller number ranges from 36.05 to 90.13 tillers/plant where accession 1087 had significantly the lowest except accession 13332 (Table 1).

The brachiaria grass accessions 14813 (24.685 t/ha) and $14721(20.89 \mathrm{t} / \mathrm{ha})$ recorded significantly $(\mathrm{p}<0.05)$ higher mean dry matter yield than all the Brachiaria accessions while 1087 (5.92 t/ha) had the lowest (Table 1). The result was high compared with that obtained by Hare et al. [7] (16.3 t/ha DM yield). However, the result is almost similar to those of Hare et al. [8] and FAO [2] who reported that DM yield of brachiaria grass up to $20 \mathrm{t} / \mathrm{ha}$. The higher dry matter yield might be due to their high tiller number, plot cover and plant height. Because the tiller numbers increased the chances of survival for most grasses and that large number of tillers produced allowed grasses to attain relatively high dry matter. The results are in agreement with Mganga [11], reporting that tillering ability increases dry matter yield.

In general, the height, plot cover and tiller number of brachiaria grass accessions 14813 and 14721 were almost similar with the tested local check, but perform significantly higher than local check (14.08 t/ha) in forage dry matter yield. The brachiaria grass accessions 14813 and 14721 had $75.36 \%$ and $48.37 \%$ forage dry matter yield advantage over the local check, respectively.

Table 1. Composite mean of plot cover, plant height, tiller number and dry matter yield of the brachiaria grass accessions tested over years and locations.

\begin{tabular}{lllll}
\hline Treatments & $\begin{array}{l}\text { Plot } \\
\text { cover\% }\end{array}$ & $\begin{array}{l}\text { Plant } \\
\text { height (cm) }\end{array}$ & $\begin{array}{l}\text { Tiller } \\
\text { number }\end{array}$ & DMY (t/ha) \\
\hline 1087 & $20.00 \mathrm{~d}$ & $66.05 \mathrm{c}$ & $36.05 \mathrm{c}$ & $5.92 \mathrm{~d}$ \\
13205 & $58.33 \mathrm{c}$ & $98.67 \mathrm{bc}$ & $90.13 \mathrm{a}$ & $9.31 \mathrm{~cd}$ \\
13332 & $69.17 \mathrm{bc}$ & $135.28 \mathrm{ab}$ & $57.67 \mathrm{bc}$ & $12.29 \mathrm{bcd}$ \\
14720 & $98.33 \mathrm{a}$ & $131.67 \mathrm{ab}$ & $73.94 \mathrm{ab}$ & $11.13 \mathrm{~cd}$ \\
14721 & $100.00 \mathrm{a}$ & $155.00 \mathrm{a}$ & $81.10 \mathrm{ab}$ & $20.89 \mathrm{ab}$ \\
14743 & $81.67 \mathrm{abc}$ & $127.17 \mathrm{ab}$ & $78.48 \mathrm{ab}$ & $12.66 \mathrm{bcd}$ \\
14771 & $90.83 \mathrm{ab}$ & $148.50 \mathrm{a}$ & $79.06 \mathrm{ab}$ & $15.30 \mathrm{bc}$ \\
14774 & $69.17 \mathrm{bc}$ & $119.17 \mathrm{ab}$ & $71.55 \mathrm{ab}$ & $8.30 \mathrm{~cd}$ \\
14813 & $100.00 \mathrm{a}$ & $143.00 \mathrm{ab}$ & $82.19 \mathrm{ab}$ & $24.69 \mathrm{a}$ \\
Local check & $98.33 \mathrm{a}$ & $131.83 \mathrm{ab}$ & $79.28 \mathrm{ab}$ & $14.08 \mathrm{bc}$ \\
CV $(\%)$ & 30.62 & 33.24 & 36.7 & 36.42 \\
p-value & $* *$ & $* *$ & $*$ & $* *$ \\
LSD $(0.05)$ & 13.89 & 24.11 & 15.457 & 4.5007 \\
\hline
\end{tabular}

LSD: least significant difference, DMY: dry matter yield, CV: coefficient of variation

\subsection{Brachiaria Grass Accessions Nutritive Value}

The composite mean of herbage chemical composition (OM\%, Ash\%, $\mathrm{CP} \%, \mathrm{NDF} \%, \mathrm{ADF} \%$ and $\mathrm{ADL} \%)$ of Brachiaria accessions during the study time are presented in Table 2. Significant $(\mathrm{p}<0.05)$ difference were observed among the tested grass accessions in $\mathrm{OM} \%, \mathrm{Ash} \%, \mathrm{CP} \%$, $\mathrm{NDF} \%, \mathrm{ADF} \%$ and $\mathrm{ADL} \%$ contents (Table 2). Brachiaria grass accession $13205(10.87 \%)$ had significantly $(\mathrm{P}<0.05)$ the highest $\mathrm{CP} \%$ content compared with the other accessions except accessions 14720 (10.34\%) and 14813 (10.03\%). The results were similar to values obtained by Villela et al. [20], who found that the brachiaria decumbens had CP content of 9.43\% in autumn and Hare et al. [7], who recorded average CP ranging from 9.8 to $11.8 \%$ for brachiaria grass. However, the results were lower than the values of $\mathrm{CP}$ ranging from 13$16 \%$ recorded by Vendramini et al. [19] for brachiaria grass. Generally, the CP content in all the Brachiaria grasses accessions ranges $8.08-10.87 \%$ (Table 2 ). This result was almost similar to the $\mathrm{CP}$ content ranging from $7-10 \%$ reported by Nguku et al. [13].

For all brachiaria accessions, the NDF\% content ranges from 57.94-64.65. The result was lower than $66.4 \%-74.3 \%$ for mulato grass that reported by Pariz et al. [15]. Comparing the contents of NDF among brachiaria accessions the highest NDF\% was significantly $(\mathrm{P}<0.05)$ obtained by accessions 1087 (64.65\%), 13332 (64.09\%), 14743 (63.93\%), 14774 $(64.10 \%)$ and the local check $(63.78 \%)$ while accessions $14720(57.94 \%)$ and $13205(58.12 \%)$ recorded the lowest NDF\% value (Table 2). The highest NDF value obtained was almost similar with above $60 \%$ of NDF contents of brachiaria ruziziensis that reported by Pariz et al. [15]. The Brachiaria accessions $14721(61.94 \%)$ and $14813(61.29 \%)$ recorded significant lower NDF than the local check $(63.78 \%)$ and consequently were more digestible than the local check. The content of ADL\% was similar between all accessions of Brachiaria grass, only accessions 1087 (5.39\%) and 14743 $(5.29 \%)$ had significantly $(\mathrm{P}<0.05)$ higher than the local check (4.56\%) (Table 2).

Table 2. Composite mean of Herbage chemical composition (OM\%, Ash\%, $C P \%, N D F \%, A D F \%$ and $A D L \%)$ of Brachiaria grass accessions.

\begin{tabular}{lllllll}
\hline Treatments & OM & Ash & CP & NDF & ADF & ADL \\
\hline 1087 & $92.127 \mathrm{a}$ & $9.63 \mathrm{a}$ & $9.17 \mathrm{bc}$ & $64.65 \mathrm{a}$ & $45.38 \mathrm{a}$ & $5.39 \mathrm{a}$ \\
13205 & $90.84 \mathrm{abc}$ & $9.09 \mathrm{abc}$ & $10.87 \mathrm{a}$ & $58.12 \mathrm{c}$ & $42.76 \mathrm{bc}$ & $4.83 \mathrm{ab}$ \\
13332 & $91.38 \mathrm{ab}$ & $8.37 \mathrm{c}$ & $8.08 \mathrm{c}$ & $64.09 \mathrm{a}$ & $41.53 \mathrm{~cd}$ & $4.91 \mathrm{ab}$ \\
Local check & $88.92 \mathrm{c}$ & $8.86 \mathrm{abc}$ & $9.06 \mathrm{bc}$ & $63.78 \mathrm{a}$ & $42.03 \mathrm{~cd}$ & $4.56 \mathrm{~b}$ \\
14720 & $89.81 \mathrm{bc}$ & $9.42 \mathrm{ab}$ & $10.34 \mathrm{ab}$ & $57.94 \mathrm{c}$ & $41.79 \mathrm{~cd}$ & $4.09 \mathrm{ab}$ \\
14721 & $90.68 \mathrm{abc}$ & $9.24 \mathrm{ab}$ & $9.13 \mathrm{bc}$ & $61.94 \mathrm{~b}$ & $41.12 \mathrm{~cd}$ & $4.83 \mathrm{ab}$ \\
14743 & $91.76 \mathrm{ab}$ & $8.86 \mathrm{abc}$ & $8.36 \mathrm{c}$ & $63.93 \mathrm{a}$ & $44.93 \mathrm{ab}$ & $5.29 \mathrm{a}$ \\
14771 & $90.42 \mathrm{abc}$ & $9.35 \mathrm{ab}$ & $9.19 \mathrm{bc}$ & $61.02 \mathrm{~b}$ & $43.12 \mathrm{abc}$ & $4.99 \mathrm{ab}$ \\
14774 & $89.30 \mathrm{c}$ & $9.23 \mathrm{ab}$ & $8.09 \mathrm{c}$ & $64.10 \mathrm{a}$ & $41.19 \mathrm{~cd}$ & $4.83 \mathrm{ab}$ \\
14813 & $90.06 \mathrm{abc}$ & $8.58 \mathrm{bc}$ & $10.03 \mathrm{ab}$ & $61.29 \mathrm{~b}$ & $40.23 \mathrm{~d}$ & $5.03 \mathrm{ab}$ \\
CV $(\%)$ & 1.31 & 6.1 & 10.05 & 1.53 & 3.47 & 12.59 \\
LSD & 0.97 & 0.45 & 0.76 & 0.78 & 1.2 & 0.31 \\
\hline
\end{tabular}

OM: Organic matter, CP: Crude protein, NDF: Neutral Detergent Fiber, ADF: Acid Detergent Fiber, ADL: Acid Detergent Lignin, LSD: least significant difference, $\mathrm{CV}$ : coefficient of variation 
Photos taken during the study time

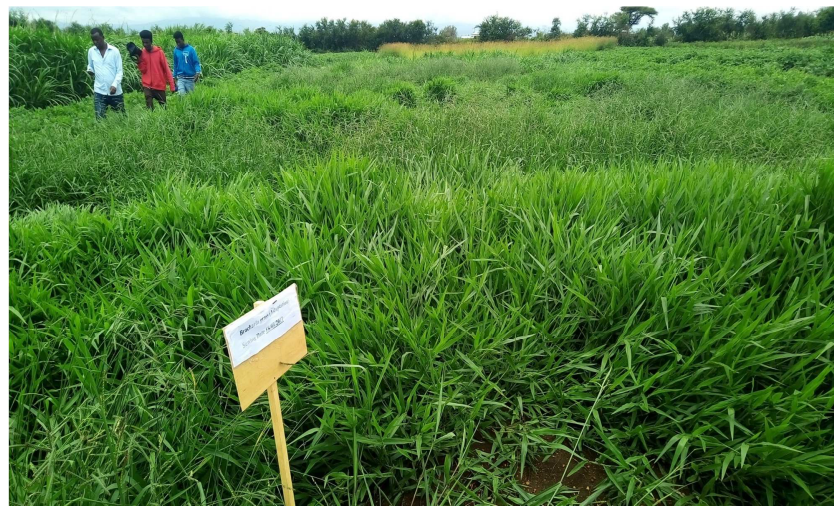

Figure 1. Brachiaria grass accessions at experimental site.

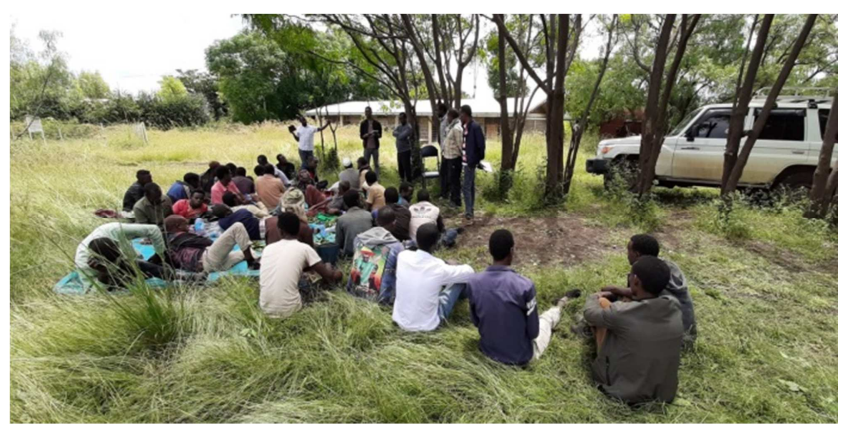

Figure 2. Farmers training on planting or establishment, management and using of brachiaria grass at experimental site.

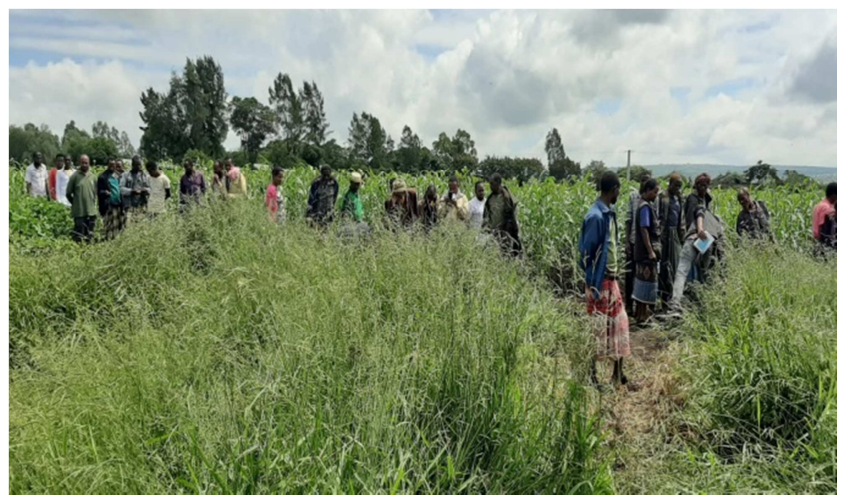

Figure 3. Farmers' field day or demonstration of brachiaria grass accessions at experimental site.

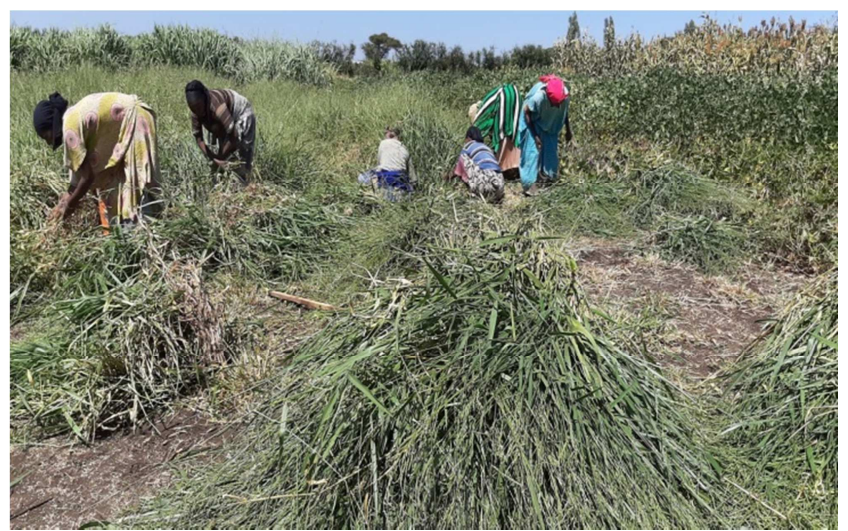

Figure 4. Women participation in brachiaria grass harvesting and uses.

\section{Conclusions and Recommendations}

The study showed that Brachiaria grass favors the production of high quantity and quality forage in the lowlands of East Oromia, Ethiopia. The Brachiaria accessions evaluated showed high adaptation and forage dry matter yield with accessions 14813 and 14721 having the highest yield in all years and locations. These two Brachiaria grass accessions performed well in terms of plot cover, plant tiller number, plant height and had appreciable dry matter yield. They had the potential to tolerate the drought areas implying that they are likely to survive in areas that receives between 650 and $750 \mathrm{~mm}$ annual rainfall. These top performing accessions yielded much greater than the controls; local check grass and the remaining tested accessions, thus they could be considered as suitable grasses for inclusion in the local farming system. Generally, the highest in forage dry matter yield and nutritive value of brachiaria grass accessions 14813 and 14721 over locations and years revealed that these accessions are better adapted and performed well as compared to the tested brachiaria accessions. Thus, they are recommended for cultivation and production in Eastern Oromia, Ethiopia and similar agro ecologies to the study area.

\section{Abbreviations}

$\begin{array}{ll}\text { ADF } & \text { Acid Detergent Fiber } \\ \text { ADL } & \text { Acid Detergent Lignin } \\ \text { CP } & \text { Crude Protein } \\ \text { DMY } & \text { Dry Matter Yield } \\ \text { FARC } & \text { Fedis Agricultural Research Center } \\ \text { NDF } & \text { Neutral Detergent Fiber } \\ \text { OARI } & \text { Oromia Agricultural Research Institute } \\ \text { OM } & \text { Organic Matter }\end{array}$

\section{Acknowledgements}

The study was financed by Oromia Agricultural Research Institute (OARI). The authors are grateful to the Institute and Fedis Agricultural Research Center of OARI (FARC) for their financial and technical support. The authors would also like to thank Dr, Tesfaye Alemu of Livestock Research Director.

\section{References}

[1] Arango J., Moreta D., Núñez J., Hartmann K., Domínguez M., Ishitani M., Miles J., Subbarao G., Peters M., Rao I. 2014. Developing methods to evaluate phenotypic variability in biological nitrification inhibition (BNI) capacity of Brachiaria grasses. Tropical Grasslands-Forrajes Tropicales, 2: 6-8.

[2] FAO, 2015. Grassland Index. A searchable catalogue of grass and forage legumes. FAO, Rome, Italy. Htt.

[3] FARC (Fedis Agricultural Research Center). 2013. Soil Chemical Analysis: Regional Review, Zeway, Ethiopia. 
[4] Fuad Abduselam, Samuel Tegene, Zeleqe Legese, Fikadu Tadesse, Alemayehu Biri and Taye Tessema. 2018. Evaluation of Early Maturing Sorghum (Sorghum bicolor (L.) Moench) Varieties, for Yield and Yield Components in the Lowlands of Eastern Hararghe. Asian Journal of Plant Science and Research, 8 (1): 40-43.

[5] Ghimire S., Njarui D., Mutimura M., Cardoso J., Johnson L., Gichangi E., Teasdale S., Odokonyero K., Caradus J., Rao I., Djikeng A. 2015. Climate-smart Brachiaria for improving livestock production in East Africa: Emerging opportunities. In Sustainable use of grassland resources for forage production, biodiversity and environmental protection.

[6] Gomez, K. A. and Gomez, A. A. 1984. Statistical procedures for agricultural research, 2nd edition. John Viley and Sons Inc., New York.

[7] Hare, M. D., Tatsapong, P. and Saipraset, K. 2007. Seed production of two Brachiaria hybrid cultivars in north-east Thailand. 1. Method and time of planting. Tropical Grasslands (2007) Volume 41, 26-34.

[8] Hare, M. D.; Phengphet, S., Songsiri, T.; Sutin, N. and Stern, E. 2013. Effect of cutting interval on yield and quality of three Brachiaria hybrids in Thailand. Tropical Grasslands-Forrajes Tropicales. 1: 84-86.

[9] Jank L., Barrios S. C., do Valle C. B., Simeão R. M., Alves G. F. 2014. The value of improved pastures to Brazilian beef production. Crop Pasture Sci., 65: 1132-1137.

[10] Maass B. L., Midega A. O., Mutimura M., Rahetlah V. B., Salgado P., Kabirizi J. M., Khan Z. R., Ghimire S., Rao, I. M. 2015. Homecoming of Brachiaria: Improved hybrids prove useful for African animal agriculture. E. Africa Agriculture and Forestry Journal, 81: 71-78.

[11] Mganga, K. 2009. Impact of grass reseeding technology on rehabilitation of degraded rangelands: A case study in Kibwezi, Kenya. MSc Thesis, University of Nairobi, Nairobi, Kenya. 14 p.

[12] Moreta D. E., Arango J., Sotelo M., Vergara D., Rincón A., Ishitani N., Castro A., Miles J., Peters M., Tohme J., Subbarao G. V., Rao I. M. 2014. Biological nitrification inhibition (BNI) in Brachiaria pastures: A novel strategy to improve ecoefficiency of crop-livestock systems and to mitigate climate change. Tropical Grasslands-Forrajes Tropicales, 2: 88-91.

[13] Nguku, S. A. 2015. An evaluation of Brachiaria grass cultivars productivity in semi-arid Kenya. MSc thesis. South Eastern Kenya University. 113 p.

[14] Njarui, D. M. G, and Wandera, F. P. 2004. Effect of cutting interval on productivity of five selected herbaceous legumes and grasses in semi-arid areas in Tropical Kenya. Tropical Grasslands. 38: 158-166.

[15] Pariz, C. M., Andreotti, M., Bergamaschine, A. F., Buzetti, S., Costa, N. R. and Cavallini, M. C. (2011) Produção, Composição Bromatológica e Índice de Clorofila de Braquiárias Após o Consórcio com Milho. Archivos de Zootecnia, 60, 1041-1052.

[16] Rao I., Ishitani M., Miles J., Peters M., Tohme J., Arango J., Moreta D. E., Lopez H., Castro A., Hoek R. V. D., Martens S., Hyman J., Tapasco J., Duitam J., Suárez H., Borrero G., Núñez J., Hartmann K., Domínguez M., Sotelo M., Vergara D., Lavelle P., Subbarao G. V., Rincon A., Plazas C., Cadisch G., Mendoza R., Rathjen, L., Karwat H. 2014. Climate-smart crop-livestock systems for smallholders in the tropics: Integration of new forage hybrids to intensify agriculture and to mitigate climate change through regulation of nitrification in soil. Tropical Grasslands-Forrajes Tropicales, 2: 130-132.

[17] Rayburn, E. B. and Lozier, J. D. 2007. Alternative Methods of estimating forage height and sward capacitance. In E. A. Rayburn, pastures can be cross calibrated. St. Paul Minnesota. USA. Plant Management Network. 59: 50-69.

[18] Renvoize, S. A., Clayton W. D., Kabuye C. H. S. 1996. Morphology, taxonomy and natural distribution of Brachiaria (Trin.) Griseb. In Brachiaria: Biology, Agronomy, and Improvement; Miles, J. W.; Maass, B. L.; do Valle C. B., Eds.; International Centre for Tropical Agriculture: Cali, Colombia, pp. 1-15. Silva P. I., Martins A. M., Gouvea E. G., PessoaFilho M., Ferreira M. E. 2013. Development and validation.

[19] Vendramini, J. M. B., Sollenberger, L. E., Soares, A. B., Da Silva, W. L., Sanchez, J. M. D., Valente, A. L., Aguiar, A. D. and Mullenix, M. K. 2014. Harvest frequency affects herbage accumulation and nutritive value of Brachiaria grass hybrids in Florida. Tropical Grasslands - Forrajes Tropicales. 2: 197-206.

[20] Villela, S. D. J., Paulino, M. F., Valadares Filho, S. C., Leão, M. I. and Figueiredo, D. M. (2008) Fontes de Proteína em Suplementos Para Abate de Bovinos em Pastejo: Período de Transição Águas-Seca. Revista Ciência Agronômica, Fortaleza, 39, 317-326.

[21] Vijaya D., Srivastava M., Gupta C., Malaviya D., Roy M., Mahanta S., Singh J., Maity A., Ghos P. Eds., New Delhi, India, pp. 361-370.

[22] Zenna T. 2016. Business and management consultancy (TZBMC), CARE ABDISHE/linking initiatives, stakeholders to achieve gender-sensitive livelihood security (LINKAGES) project end line evaluation report. 